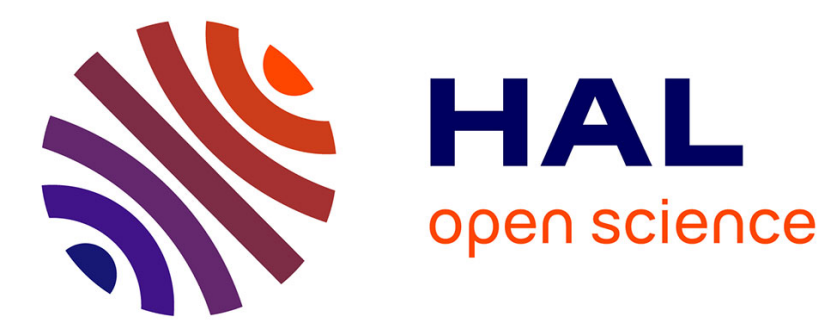

\title{
Chemoenzymatic synthesis of 5-thio-D-xylopyranose.
} Franck Charmantray, Philippe Dellis, Virgil Hélaine, Soth Samreth, Laurence Hecquet

\section{To cite this version:}

Franck Charmantray, Philippe Dellis, Virgil Hélaine, Soth Samreth, Laurence Hecquet. Chemoenzymatic synthesis of 5-thio-D-xylopyranose.. European Journal of Organic Chemistry, 2006, pp.55265532. 10.1002/ejoc.200600627 . hal-00121152

\section{HAL Id: hal-00121152 https://hal.science/hal-00121152}

Submitted on 26 Feb 2007

HAL is a multi-disciplinary open access archive for the deposit and dissemination of scientific research documents, whether they are published or not. The documents may come from teaching and research institutions in France or abroad, or from public or private research centers.
L'archive ouverte pluridisciplinaire HAL, est destinée au dépôt et à la diffusion de documents scientifiques de niveau recherche, publiés ou non, émanant des établissements d'enseignement et de recherche français ou étrangers, des laboratoires publics ou privés. 


\title{
Chemoenzymatic Synthesis of 5-Thio-D-xylopyranose
}

\author{
Franck Charmantray, ${ }^{|\mathrm{a}|}$ Philippe Dellis, ${ }^{|\mathrm{b}|}$ Virgil Hélaine, ${ }^{\mid \mathrm{al}}$ Soth Samreth, ${ }^{\mid \mathrm{cl}}$ and \\ Laurence Hecquet*|a|
}

Keywords: Biocatalysis / C-C bond formation / Carbohydrates / Isomerisation

5-thio-D-xylopyranose, a synthon used for the preparation of drugs with antithrombotic activity, was synthesised by an enzymatic isomerisation from the corresponding ketose, 5 -thioD-xylulofuranose, with glucose isomerase. This compound was obtained by two different chemoenzymatic routes, the key step being the stereospecific formation of a $\mathrm{C}-\mathrm{C}$ bond, catalysed by transketolase or fructose-1,6-bisphosphate aldolase.

(๑ Wiley-VCH Verlag GmbH \& Co. KGaA, 69451 Weinheim, Germany, 2006)

\section{Introduction}

Its sulphur-in-the-ring moiety ${ }^{[1]}$ lends 5 -thio-D-xylopyranose (1) interesting biological properties. This compound is an inhibitor of $\beta$-D-xylosidase ${ }^{[2]}$ and a useful chiral building block for the synthesis of D-xylopyranosides displaying antithrombotic activity (Scheme 1). Current therapies with venous antithrombotic agents use either indirect anticoagulants of the dicoumarol type or a heparin biopolymer. Each of these therapeutic classes has both advantages and limitations. Desirable features of an ideal agent would be rapid onset of action at the target, no side effects, easy monitoring and oral administration. The effects of $\beta$-D-xylopyranosides including dicoumarol-like compounds have been studied in animal models by oral administration. ${ }^{[3,4]}$

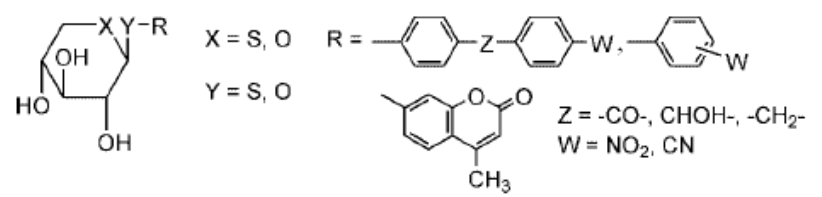

Scheme 1. 5-Thio-D-xylopyranosides derivatives tested as oral venous antithrombotics.

The replacement of the oxygen by sulphur in the sugar ring was found to increase potency. Hence, the 5-thio-Dxylopyranose moiety of 5-thio- $\beta$-D-xylopyranosides constituted a good pharmacophore for oral antithrombotic activity (Scheme 2). Clinical studies with some of these compounds are in progress. For instance, odiparcil, ${ }^{[3,4]}(\mathrm{X}=\mathrm{S}$,

[a] Laboratoire SEESIB, UMR 6504 CNRS, Université Blaise Pascal, 24 avenue des Landais, 63177 Aubière, France E-mail: Laurence.HECQUET@univ-bpclermont.fr

[b] Synkem,

47 rue de Longvic, 21300 Chenôve, France

[c] Fournier Pharma,

50 rue de Dijon, 21121 Daix, France
$\mathrm{Y}=\mathrm{O}$ and $\mathrm{R}=$ methylcoumarin in Scheme 1) is currently undergoing Phase II clinical trials.

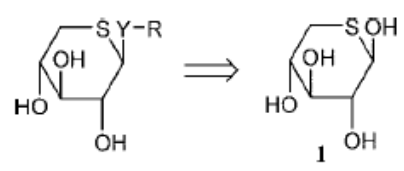

Scheme 2. The 5-thio-D-xylopyranose moiety.

Various methods for producing these glycosides in a highly stereoselective manner have been described. ${ }^{[5-7]}$

Here we report the synthesis of the aldose 5-thio-D-xylopyranose (1). General chemical routes have been described from D-xylopyranose involving protection/deprotection and replacement with nucleophilic sulphur-containing reagents. ${ }^{[3,8,9]}$ Since the first synthesis of 1 was reported, ${ }^{[10]}$ Bellamy et al. ${ }^{[4]}$ have published a five-step synthesis of thioaldose 1 from D-xylose in $36.5 \%$ overall yield. More recently, Lalot and co-workers ${ }^{[11]}$ reported the five-step synthesis of 1 from D-xylono-1,4-lactone in $42 \%$ overall yield.

In the field of monosaccharide synthesis, an enzymatic approach is particularly attractive, as enzymes usually exhibit high regio- and stereoselectivity, and the reactions proceed under gentle conditions. The preparation of ketoses and analogues has been largely described with enzymes catalysing stereoselective $\mathrm{C}-\mathrm{C}$ bond formation such as transketolases and aldolases. Access to aldoses from corresponding ketoses was proposed by Wong et al. ${ }^{[12]}$ based on enzymatic ketol-aldol isomerisation. The efficiency of this rather general approach was initially reported on for the synthesis of D-glucose derivatives ${ }^{[13]}$ with commercially available fructose-1,6-bisphosphate aldolase (FruA, EC 4.1.2.13) and glucose isomerase (GlcI, EC 5.3.1.5) and by Fessner and co-workers for the synthesis of L-fucose analogues ${ }^{[14]}$ with L-fuculose 1-phosphate aldolase (FucA, EC 4.1.2.17) and L-fucose isomerase (FucI, EC 5.3.1.3). 
In this paper, we investigated two different chemoenzymatic strategies to obtain 5-thio-D-xylopyranose (1) based on ketol-aldol enzymatic isomerisation.

\section{Results and Discussion}

Our retrosynthetic approach (Scheme 3) was based on a two-step sequence. An enzymatic ketol-aldol isomerisation of 5-thio-D-xylulofuranose (2) to 5-thio-D-xylopyranose (1) was catalysed by GlcI. Enzymes catalysing $\mathrm{C}-\mathrm{C}$ bond formation were used to prepare ketose 2. Two enzymes used in organic synthesis are able to create a D-threo $(3 S, 4 R)$ ketose moiety: a transferase, transketolase $\mathrm{e}^{[15]}(\mathrm{TK}$, Route A) and a lyase, FruA ${ }^{[16]}$ (Route B). These enzymes require donor and acceptor substrates. TK transfers a ketol with two carbon units from a donor substrate, hydroxypyruvate (used for synthetic purposes because the reaction becomes irreversible) to an $\alpha$-hydroxyaldehyde of $R$ configuration. The $\mathrm{C} 2-\mathrm{C} 3$ bond is formed, and the new asymmetric carbon is in an $S$ configuration. Aldolases catalyse an aldol addition reaction. The ones most widely used in organic synthesis are DHAP-aldolases such as fructose-1,6-bisphosphate aldolase (FruA). This enzyme catalyses the aldol condensation of DHAP (Dihydroxy Acetone Phosphate), a ketol with three carbon units, with an $\alpha$-hydroxyaldehyde, and forms the $\mathrm{C} 3-\mathrm{C} 4$ bond, giving $(3 S, 4 R)$ stereochemistry.

\section{TK Catalysed the Synthesis of 5-Thio-D-xylulofuranose (Route A)}

As TK is generally highly enantioselective towards $\alpha$-hydroxylated aldehydes as acceptor substrates, compound 3 could be prepared in a racemic form. It was obtained in a three-step sequence starting from commercially available acrolein diethyl acetal 6 (Scheme 4). This underwent epoxidation with hydrogen peroxide as the oxidising agent in $60 \%$ yield. ${ }^{[17]}$ Regioselective ring opening of the epoxide in 5 was carried out with potassium thiolate made in situ by bubbling a stream of $\mathrm{H}_{2} \mathrm{~S}$ into aqueous $\mathrm{KOH} \cdot{ }^{[18]}$ Under these conditions, compound 4 was obtained in $95 \%$ yield. Subsequent hydrolysis of the acetal to the aldehyde was achieved with an acidic resin in water giving 3 in quantitative yield, immediately available for enzymatic condensation without further purification.

As described by Effenberger et al., ${ }^{[19]}$ compound 3 was a substrate of TK, and it was possible to run the enzymatic reaction on a preparative scale with concentrations of substrate 3 up to $250 \mathrm{~mm}$. The best yield obtained was $24 \%$

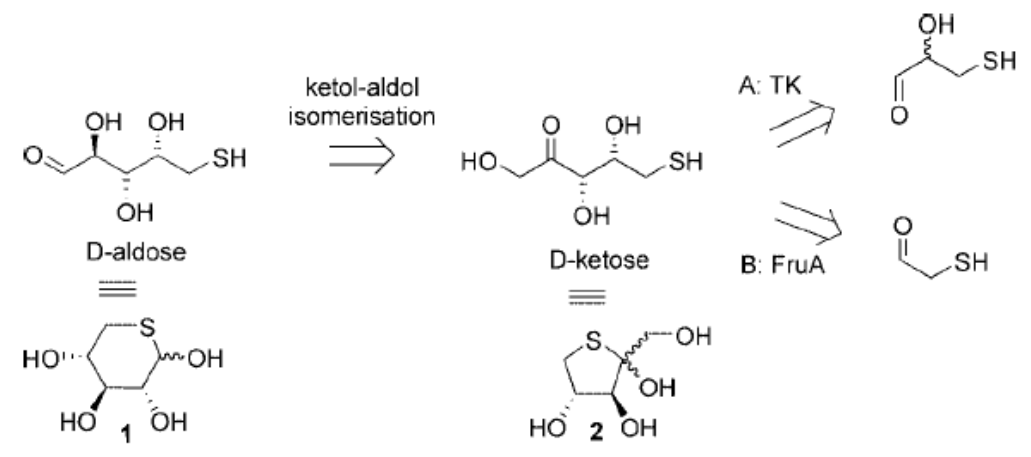

Scheme 3. The 5-thio-D-xylopyranose retrosynthetic pathway; Route A: catalysed by transketolase (TK), Route B: catalysed by fructose1,6-bisphosphate aldolase (FruA).

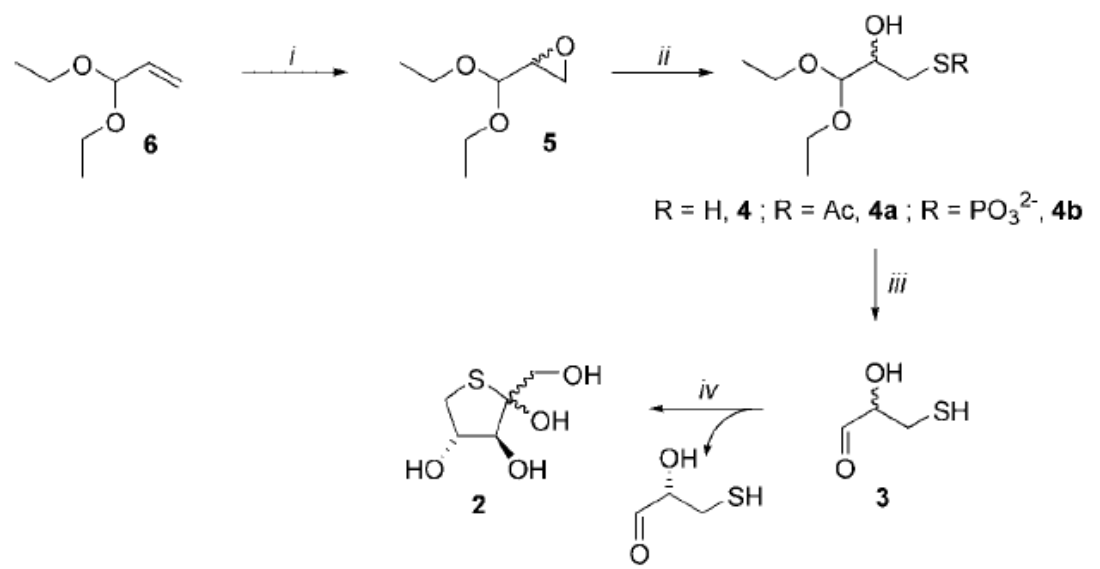

Scheme 4. Route A catalysed by TK; i: $\mathrm{KHCO}_{3}, \mathrm{PhCN}, \mathrm{H}_{2} \mathrm{O}_{2}, 60 \%$; ii: $\mathrm{H}_{2} \mathrm{~S}, \mathrm{KOH}, 95 \%$ or AcSK$/ \mathrm{AcSH}, 63 \%$ or $\mathrm{Na}_{3} \mathrm{SPO}_{3} / \mathrm{H}_{2} \mathrm{O}, 70 \%$; iii: Dowex $\mathrm{H}^{+}, 100 \%$; iv: TK, $\mathrm{HOCH}_{2} \mathrm{COCO}_{2} \mathrm{Li}, 24 \%$. 
(based on the racemic acceptor substrate), which is lower than the yield stated by Effenberger et al. on an analytical scale. A free thiol may inactivate TK. Thus, as an alternative to improve the yield, we used compound 3, protected on its thiol function as a thioacetate or thiophosphate. Epoxide opening with either potassium thioacetate in thioacetic acid or sodium thiophosphate in water proceeded smoothly to give the corresponding compound $4 a$ or $4 \mathbf{b}$ in $63 \%$ or $70 \%$ yield, respectively. Unfortunately, the acetal group could not be hydrolysed under various acidic conditions without loss of the protective group, which invariably led back to compound 3 . To improve the yield, we turned to another enzyme able to form a $\mathrm{C}-\mathrm{C}$ bond with $(3 S, 4 R)$ stereochemistry, FruA.

\section{FruA Catalysed the Synthesis of 5-Thio-D-xylulofuranose 2 (Route B)}

\section{Route B1}

Our initial goal was to improve the conditions reported in the literature for the straightforward enzymatic synthesis of 5-thio-D-xylulofuranose (2) catalysed by FruA from DHAP and 1,4-dithiane-2,5-diol (Scheme 5). ${ }^{[18]}$ The effectiveness of the synthesis was hampered by inhibition of FruA by the starting aldehyde itself. After $1.25 \mathrm{~h}$ at $37^{\circ} \mathrm{C}$, FruA activity was halved in the presence of 1,4-dithiane2,5-diol as the acceptor $(10 \mathrm{~mm}){ }^{[20]}$ As a result, a large amount of FruA ( $7 \mathrm{U} / \mathrm{mL}$ of reaction mixture) was necessary to fully convert the starting aldehyde. Also, the substrate inhibition limited the final concentration of 5-thio-Dxylulofuranose (2) to $10 \mathrm{~mm}$ in the reaction mixture. As with TK, substrates bearing a free thiol function may cause irreversible inactivation of FruA. Thus Route B1 was not suitable for large scale synthesis of compound 2. Accordingly, we sought another strategy.

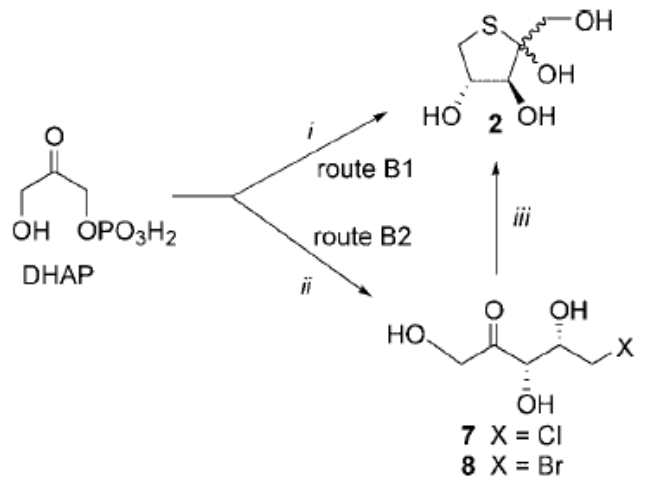

Scheme 5. FruA-catalysed aldolisation reaction from DHAP; i: a: $\left(\mathrm{C}_{2} \mathrm{H}_{4} \mathrm{SO}\right)_{2}$, FruA, pH 7.5, b: acid phosphatase (Pase), pH 4.7, $60 \%$; ${ }^{[18]}$ ii: a: $\mathrm{XCH}_{2} \mathrm{CHO}$, FruA, pH 7.5, b: Pase, $\mathrm{pH} 4.7,71 \%(7)$ or $55 \%$ (8); iii: $\mathrm{Na}_{3} \mathrm{SPO}_{3}, 55 \%$ (from 7 or 8); or $\mathrm{NaSH}, 57 \%$ (from 7) or $61 \%$ (from 8 ).

\section{Route B2}

Our goal in this approach was to avoid the use of an aldehydic acceptor substrate with a free thiol function. We introduced the thiol after the reaction catalysed by FruA. According to analytical studies reported in the literature, haloaldehydes such as 2-chloro or 2-bromo acetaldehyde lead to high initial velocities with FruA. We investigated the preparation of haloxyluloses that could be further substituted by a thiol with a non-enzymatic procedure (Scheme 5).

\section{Synthesis of Haloxyluloses 7 and 8}

In the first step, DHAP and 2-chloro- or 2-bromoacetaldehyde were condensed with FruA. The reactions yielded either 5-chloro-D-xylulose-1-phosphate or 5-bromo-D-xylulose-1-phosphate. These intermediates were not isolated but readily submitted to ester hydrolysis with acid phosphatase type XA (EC 3.1.3.2, from sweet potato, Pase). After purification by column chromatography, 5-chloro-D-xylulose (7) was obtained in $71 \%$ yield, whereas 5-bromo-D-xylulose (8) was obtained in $55 \%$ yield (Scheme 5).

\section{Halogen Displacement}

Two strategies were investigated. We used an efficient method ${ }^{[21]}$ described for tosylated compounds by adding the thiophosphate under acidic conditions. The phosphorylated thiosugars thus obtained decomposed in situ to give the free thiol sugar. Conversion of 5-chloro-D-xylulose (7) or 5-bromo-D-xylulose (8) into 5-thio-D-xylulofuranose (2) was achieved by nucleophilic substitution with $\mathrm{Na}_{3} \mathrm{SPO}_{3}$ reagent in water, followed by thioester hydrolysis at $\mathrm{pH}$ 4.0. 2 was recovered in $55 \%$ yield after purification by column chromatography. One major limitation of this method was the cost of the sodium thiophosphate, which precluded large-scale synthesis. We circumvented this problem by converting 5-halo-D-xyluloses $\mathbf{7}$ and $\mathbf{8}$ directly into compound 2 with sodium sulfide as the nucleophilic reagent. After completion of the reaction at $\mathrm{pH} 9.5$ in water, the crude mixture was purified by column chromatography to give compound 2, isolated in $57 \%$ and $61 \%$ yield from 7 and $\mathbf{8}$, respectively.

In conclusion, Route B2 appeared more suitable than A or B1. Compound 2 was obtained in two steps in an overall yield of $40 \%$ from DHAP. We note that DHAP can be prepared by a chemical route, ${ }^{[2]}$ and we have recently described an easy, efficient and cheap two-step synthesis of DHAP from 2,3-epoxypropanol (rac-glycidol). ${ }^{[23]}$

\section{Enzymatic Isomerisation of 5-Thio-D-xylulofuranose (2) to} 5-Thio-D-xylopyranose (1)

We converted 2 into 1 by a ketol-aldol enzymatic isomerisation (Scheme 6). ${ }^{[12-14]}$ This reaction was catalysed by GlcI with a cocktail of divalent cations $\left(\mathrm{Mg}^{2+}, \mathrm{Mn}^{2+}\right.$ and $\mathrm{Co}^{2+}, 1 \mathrm{~mm}$ each). In vivo, this enzyme catalyses the reversible isomerisation of D-xylose or D-glucose into D-xylulose or D-fructose (the ratio at equilibrium is in favour of the aldose). This enzyme is widely used in industry in its immobilized form for the large-scale conversion of D-glucose into D-fructose. ${ }^{[2]}$ The isomerisation of $\mathbf{2}$ was followed by 
HPLC with a refractometer as the detector. To increase the ratio in favour of the aldose, we tested different reaction conditions (Table 1). We varied the starting material concentrations from $100 \mathrm{~mm}$ to $200 \mathrm{~mm}$ along with the frequency of GlcI addition. The ketose/aldose ratio increased in favour of the aldose with time and the quantity of GlcI. The best result (ketose/aldose, 40:60) was obtained for $100 \mathrm{~mm}$ after $8 \mathrm{~d}$ at $48^{\circ} \mathrm{C}$ (the optimum temperature for $\mathrm{GlcI}$ ) and with $415 \mathrm{U}$ of GlcI added portionwise (45 U every $24 \mathrm{~h}$, Table 1 , entry 4 ).

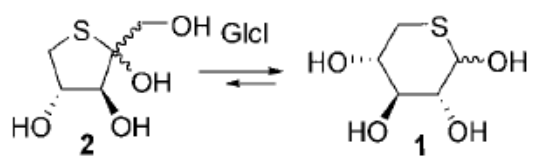

Scheme 6. Enzymatically catalysed ketol-aldol isomerisation.

Table 1. GlcI-catalysed interconversion of 5-thio-D-xylulofuranose (2) into 5-thio-D-xylopyranose (1).

\begin{tabular}{ccccc}
\hline Experiment & $\begin{array}{c}\text { Substrate ketose 2 } \\
{[\mathrm{mM}]}\end{array}$ & $\begin{array}{c}\text { GlcI } \\
{[\mathrm{U}]^{[\mathrm{a}]}}\end{array}$ & $\begin{array}{c}\text { Reaction time } \\
{[\mathrm{d}]}\end{array}$ & Ketose 2/aldose 1 \\
\hline 1 & 100 & $45^{[\mathrm{b}]}$ & 4 & $77: 22$ \\
2 & 100 & $315^{[\mathrm{c}]}$ & 4 & $60: 40$ \\
3 & 100 & $45^{[\mathrm{b}]}$ & 8 & $65: 35$ \\
4 & 100 & $315^{[\mathrm{c}]}$ & 8 & $40: 60$ \\
5 & 200 & $45^{[\mathrm{b}]}$ & 4 & $84: 16$ \\
6 & 200 & $315^{[\mathrm{c}]}$ & 4 & $71: 28$ \\
7 & 200 & $45^{[\mathrm{b}]}$ & 8 & $77: 23$ \\
8 & 200 & $315^{[\mathrm{c}]}$ & 8 & $57: 43$ \\
\hline
\end{tabular}

[a] $1 \mathrm{U}$ (unit) is defined as the amount of enzyme that converts glucose to fructose at an initial rate of $1 \mu \mathrm{mol} / \mathrm{min}$ under standard analytical conditions. [b] Addition of all the GlcI at time zero. [c] Portionwise addition of $45 \mathrm{U}$ of GlcI every $24 \mathrm{~h}$.

Under these conditions, compound 1 was isolated in its two isomeric forms $(\alpha / \beta$ ratio, $87: 13)$ in $60 \%$ yield after semi-preparative HPLC.

\section{Conclusions}

We performed a new chemoenzymatic synthesis of 5thio-D-xylopyranose based on the GlcI reaction of the corresponding thioketose 2 . To the best of our knowledge, enzymatic isomerisation of a thioketose into a thioaldose on a preparative scale had never been described before.

Two routes to prepare 2, catalysed by FruA or TK, have been investigated. The use of an acceptor substrate with a free thiol function is rate-limiting for these enzymes. We have developed an efficient enzymatic route catalysed by FruA, in which the acceptor substrate is a haloaldehyde and the donor substrate is DHAP, leading to 5-halo-D-xylulose 7 or 8 . The thiol was introduced after the enzymatic step by displacement of the halogen by $\mathrm{NaSH}$. After isomerisation, the overall yield of 1 was $23 \%$ from commercially available 2-chloroacetaldehyde.

This chemoenzymatic strategy offers an attractive alternative to conventional chemical methods because of its stereochemical control, mild conditions and no requirement for a protecting group. To improve the yield of the isomeri- sation of thioketose 2 into thioaldose 1, recycling of unreacted 2 could be considered, as in the industrial production of D-fructose from D-glucose.

\section{Experimental Section}

General Experimental Information: Chemicals and solvents were purchased from Aldrich and Acros and were reagent grade. L-glycerol-3-phosphate oxidase, L-GPO, (EC 1.1.3.21, from Thermophilus bacillus), catalase (EC 1.11.1.6, from bovine liver), fructose-1,6-bisphosphate aldolase (EC 4.1.2.13, from rabbit muscle), acid phosphatase type XA (EC 3.1.3.2, from sweet potato), $\alpha$-glycerophosphate dehydrogenase type I (EC 1.1.1.8, from rabbit muscle) and peroxidase type I (EC 1.11.1.7, from horseradish) were used as received from Sigma Chem. Co. Immobilised glucose isomerase (EC 5.3.1.5, from Streptomyces murinus, Sweetzyme $(\mathbb{R})$, was purchased from Novozyme. TK crude extract comes from the yeast strain H402. ${ }^{[15 e, 25]}$ Merck 60 F254 silica gel TLC plates and Merck 60/ $230-400$ and 60/40-63 mesh silica gel for column chromatography were used. ${ }^{1} \mathrm{H},{ }^{13} \mathrm{C}$ and ${ }^{31} \mathrm{P}$ NMR spectra were recorded with a Bruker Avance 400 spectrometer in $\mathrm{CDCl}_{3}, \mathrm{D}_{2} \mathrm{O}$, or $\mathrm{CD}_{3} \mathrm{OD}$. $\delta$ values are given in parts per million (ppm) and $J$ values in Hertz. MS and HRMS were recorded with a Micromass Q-Tof spectrometer equipped with an electrospray ionisation source. HPLC analyses of 1 were performed with a $\mu$ Bondapak $\mathrm{NH}_{2}$ column $(4.0 \mathrm{~mm} \times 150 \mathrm{~mm})$ adopting the following conditions: $\mathrm{CH}_{3} \mathrm{CN} /$ $\mathrm{H}_{2} \mathrm{O}, 95: 5 \mathrm{v} / \mathrm{v}, 1.5 \mathrm{mLmin}^{-1}, 25^{\circ} \mathrm{C}$ and with a refractometer as the detector.

Assay for DHAP Monitoring: DHAP concentration was determined enzymatically with NADH-consuming $\alpha$-glycerophosphate dehydrogenase. [26]

Assay for Hydroxypyruvate Monitoring: Hydroxypyruvate concentration was determined enzymatically with NADH-consuming lactate dehydrogenase. ${ }^{[15 \mathrm{e}]}$

Glycidaldehyde Diethyl Acetal (5): To a suspension of $\mathrm{KHCO}_{3}$ $(4.52 \mathrm{~g}, 45 \mathrm{mmol})$ in methanol $(150 \mathrm{~mL})$, commercially available acrolein diethyl acetal $(45 \mathrm{~mL}, 34.8 \mathrm{~g}, 395 \mathrm{mmol})$, benzonitrile $(28 \mathrm{~mL})$ and $\mathrm{H}_{2} \mathrm{O}_{2}(35 \%, 27 \mathrm{~mL}, 313 \mathrm{mmol})$ were added. The solution was heated in a water bath at $40^{\circ} \mathrm{C}$ for $8 \mathrm{~h} . \mathrm{H}_{2} \mathrm{O}_{2}(10 \mathrm{~mL})$ was added, followed by an additional $10 \mathrm{~mL} 8 \mathrm{~h}$ later. The resulting mixture was stirred for $20 \mathrm{~h}$. Water $(200 \mathrm{~mL})$ was poured in, and the solution was extracted with $\mathrm{CH}_{2} \mathrm{Cl}_{2}(4 \times 50 \mathrm{~mL})$. The combined organic phases were dried on $\mathrm{MgSO}_{4}$, and the solvents were evaporated under vacuum. $n$-Hexane $(150 \mathrm{~mL})$ was added to the residue thus obtained, and the precipitate of benzamide was filtered off. After evaporation of the filtrate under reduced pressure, crude compound 5 was distilled ( $\mathrm{bp}=86^{\circ} \mathrm{C}$ under 50 Torr) to give a pale yellow oil in $60 \%$ yield $(26 \mathrm{~g})$. ${ }^{1} \mathrm{H}$ NMR $\left(400 \mathrm{MHz}, \mathrm{CDCl}_{3}\right): \delta=$ $1.12\left(2 \mathrm{t}, J=6 \mathrm{~Hz}, 6 \mathrm{H}, 2 \times \mathrm{CH}_{3}\right), 2.65(\mathrm{~m}, 2 \mathrm{H}, 3-\mathrm{H}), 3.00(\mathrm{~m}, 1$ $\mathrm{H}, 2-\mathrm{H}), 3.52\left(\mathrm{~m}, 2 \mathrm{H}, \mathrm{CH}_{2}\right), 3.67\left(\mathrm{~m}, 2 \mathrm{H}, \mathrm{CH}_{2}\right), 4.26(\mathrm{~d}, J=4 \mathrm{~Hz}$, $1 \mathrm{H}, 1-\mathrm{H}) \mathrm{ppm} .{ }^{13} \mathrm{C}$ NMR $\left(100 \mathrm{MHz}, \mathrm{CDCl}_{3}\right): \delta=15.0\left(\mathrm{CH}_{3}\right), 43.4$ $\left(\mathrm{C}^{3}\right), 51.6\left(\mathrm{C}^{2}\right), 62.1\left(\mathrm{CH}_{2}\right), 62.6\left(\mathrm{CH}_{2}\right), 103.3\left(\mathrm{C}^{1}\right) \mathrm{ppm}$.

3-Thioglyceraldehyde Diethyl Acetal (4): Into a solution of $\mathrm{KOH}$ $(3.83 \mathrm{~g}, 68.4 \mathrm{mmol})$ in methanol $(15 \mathrm{~mL})$ at $0{ }^{\circ} \mathrm{C}$ was bubbled a stream of $\mathrm{H}_{2} \mathrm{~S}$ for $1 \mathrm{~h}$. A solution of compound $5(5 \mathrm{~g}, 34.2 \mathrm{mmol})$ in methanol $(10 \mathrm{~mL})$ was added dropwise for 30 min under a $\mathrm{H}_{2} \mathrm{~S}$ atmosphere. The mixture was then stirred until it reached room temperature. The solution was stirred for a further $1 \mathrm{~h}$ at room temperature and then poured into ice-water $(150 \mathrm{~mL})$. The $\mathrm{pH}$ was adjusted to 2 with a $\mathrm{H}_{2} \mathrm{SO}_{4}(5 \mathrm{~N})$ with cooling, and the solution was extracted with $\mathrm{CH}_{2} \mathrm{Cl}_{2}(5 \times 50 \mathrm{~mL})$. The combined organic 
phases were washed with saturated aq $\mathrm{NaHCO}_{3}(20 \mathrm{~mL})$ and water $(20 \mathrm{~mL})$ and dried with $\mathrm{MgSO}_{4}$. After evaporation under vacuum, a yellow oil was obtained in $95 \%$ yield $(5.8 \mathrm{~g}) .{ }^{1} \mathrm{H}$ NMR $(400 \mathrm{MHz}$, $\left.\mathrm{CDCl}_{3}\right): \delta=1.17\left(\mathrm{td}, J=7 \mathrm{~Hz}, 6 \mathrm{H}, 2 \times \mathrm{CH}_{3}\right), 1.57(\mathrm{t}, J=8 \mathrm{~Hz}$, $1 \mathrm{H}, \mathrm{SH}), 2.6$ (ddd, $J=7,8,14 \mathrm{~Hz}, 1 \mathrm{H}, 3-\mathrm{H}), 2.64(\mathrm{~s}, 1 \mathrm{H}, \mathrm{OH})$, 2.75 (ddd, $J=4,8,14 \mathrm{~Hz}, 1 \mathrm{H}, 3-\mathrm{H}), 3.55$ (qd, $J=7,10 \mathrm{~Hz}, 2 \mathrm{H}$, $\left.\mathrm{CH}_{2}\right), 3.62$ (ddd, $\left.J=4,6,7 \mathrm{~Hz}, 1 \mathrm{H}, 2-\mathrm{H}\right), 3.72(\mathrm{qd}, J=7,10 \mathrm{~Hz}, 1$ $\left.\mathrm{H}, \mathrm{CH}_{2} \mathrm{O}\right), 4.43(\mathrm{~d}, J=6 \mathrm{~Hz}, 1 \mathrm{H}, 1-\mathrm{H}) \mathrm{ppm} .{ }^{13} \mathrm{C}$ NMR $(100 \mathrm{MHz}$, $\left.\mathrm{CDCl}_{3}\right): \delta=15.3\left(\mathrm{CH}_{3}\right), 26.7(\mathrm{C}-3), 63.5\left(\mathrm{CH}_{2}\right), 63.8\left(\mathrm{CH}_{2}\right), 72.4$ (C-2), 103.5 (C-1) ppm.

3-Acetylthioglyceraldehyde Diethyl Acetal (4a): To a solution of potassium thioacetate $(962 \mathrm{mg}, 8.3 \mathrm{mmol})$ in thioacetic acid $(5.6 \mathrm{~mL})$ and $\mathrm{CH}_{2} \mathrm{Cl}_{2}(20 \mathrm{~mL})$ was added dropwise compound $3(2.23 \mathrm{~g}$, $15.9 \mathrm{mmol})$ at $-78{ }^{\circ} \mathrm{C}$ under argon. The mixture was stirred at $-78^{\circ} \mathrm{C}$ for $1 \mathrm{~h}$ and for $38 \mathrm{~h}$ at room temperature. After filtration, the solution was poured onto ice, and the aqueous phase was extracted with $\mathrm{CH}_{2} \mathrm{Cl}_{2}(3 \times 20 \mathrm{~mL})$. The combined organic phases were washed with saturated aq $\mathrm{NaHCO}_{3}$ and brine. After drying with $\mathrm{MgSO}_{4}$ and purifying by column chromatography on silica gel (cyclohexane/ethyl acetate, 8:2), $2.2 \mathrm{~g}$ of a yellow oil was obtained (63\% yield). ${ }^{1} \mathrm{H}$ NMR ( $400 \mathrm{MHz}, \mathrm{CDCl}_{3}$ ): $\delta=1.15$ (t, $J=$ $\left.7 \mathrm{~Hz}, 6 \mathrm{H}, \mathrm{CH}_{3}\right), 2.26$ (s, $\left.3 \mathrm{H}, \mathrm{CH}_{3}\right), 2.65(\mathrm{~s}, 1 \mathrm{H}, \mathrm{OH}), 2.9$ (dd, $J$ $=8,14 \mathrm{~Hz}, 1 \mathrm{H}, 3-\mathrm{H}), 3.18(\mathrm{dd}, J=4,14 \mathrm{~Hz}, 1 \mathrm{H}, 3-\mathrm{H}), 3.5(\mathrm{~m}$, $\left.2 \mathrm{H}, \mathrm{CH}_{2}\right), 3.67\left(\mathrm{~m}, 3 \mathrm{H}, \mathrm{CH}_{2}, 2-\mathrm{H}\right), 4.3(\mathrm{~d}, J=5 \mathrm{~Hz}, 1 \mathrm{H}, 1-\mathrm{H})$ ppm. ${ }^{13} \mathrm{C}$ NMR $\left(100 \mathrm{MHz}, \mathrm{CDCl}_{3}\right): \delta=15.2\left(\mathrm{CH}_{3}\right), 30.3\left(\mathrm{CH}_{3}\right)$, $31.2(\mathrm{C}-3), 62.5\left(\mathrm{CH}_{2}\right), 63.7\left(\mathrm{CH}_{2}\right), 70.9(\mathrm{C}-2), 103.5(\mathrm{C}-1), 195.9$ (CO) $\mathrm{ppm}$.

3-Thiophosphateglyceraldehyde Diethyl Acetal (4b): Sodium thiophosphate $(2.7 \mathrm{~g}, 6.8 \mathrm{mmol})$ was added to a solution of compound $3(1 \mathrm{~g}, 6.8 \mathrm{mmol})$ in water $(20 \mathrm{~mL})$. The reaction mixture was then stirred for $4 \mathrm{~h}$ at room temperature. After evaporation of water under vacuum, $2.1 \mathrm{~g}$ of a white solid was obtained $\left(70 \%\right.$ yield). ${ }^{1} \mathrm{H}$ NMR (400 MHz, $\left.\mathrm{D}_{2} \mathrm{O}\right): \delta=1.26\left(\mathrm{t}, J=7 \mathrm{~Hz}, 6 \mathrm{H}, \mathrm{CH}_{3}\right), 2.86(\mathrm{dd}$, $J=9,14 \mathrm{~Hz}, 1 \mathrm{H}, 3-\mathrm{H}), 3.33(\mathrm{dd}, J=4,14 \mathrm{~Hz}, 1 \mathrm{H}, 3-\mathrm{H}), 3.73$ $\left(\mathrm{m}, 2 \mathrm{H}, \mathrm{CH}_{2}\right), 3.84\left(\mathrm{~m}, 2 \mathrm{H}, \mathrm{CH}_{2}, 2-\mathrm{H}\right), 4.6(\mathrm{~d}, J=6 \mathrm{~Hz}, 1 \mathrm{H}, 1-$ H) ppm. ${ }^{13} \mathrm{C}$ NMR $\left(100 \mathrm{MHz}, \mathrm{D}_{2} \mathrm{O}\right): \delta=17.2\left(\mathrm{CH}_{3}\right), 34.5(\mathrm{C}-3)$, $66.8\left(\mathrm{CH}_{2}\right), 67.3\left(\mathrm{CH}_{2}\right), 74.8(\mathrm{C}-2), 106.5(\mathrm{C}-1) \mathrm{ppm}$.

3-Thioglyceraldehyde (3): An aqueous solution of compound 4 (1 g, $5.54 \mathrm{mmol})$ in water $(32 \mathrm{~mL})$ was treated with Dowex 50WX8 resin $\left(\mathrm{H}^{+}\right.$form, $800 \mathrm{mg}$ ) for $24 \mathrm{~h}$. Compound 3 thus obtained (in quantitative yield) was used in the next step without further purification.

5-Thio-D-xylulofuranose (2): In a $100 \mathrm{~mL}$ flask, Tris buffer $(0.2 \mathrm{M}$, $1.36 \mathrm{~g})$, lithium hydroxypyruvate $(25 \mathrm{mM}, 154 \mathrm{mg})$, compound 3 $(175 \mathrm{~mm}, 16 \mathrm{~mL}), \mathrm{MgCl}_{2}(3 \mathrm{mM}, 34 \mathrm{mg})$ and thiamine pyrophosphate $(2 \mathrm{mM}, 52 \mathrm{mg})$ were added to water $(35 \mathrm{~mL})$. The $\mathrm{pH}$ of the solution was adjusted to 7.5 and yeast TK $(200 \mathrm{U})$ was added. The reaction mixture was stirred at $30^{\circ} \mathrm{C}$ under argon until complete disappearance of $\alpha$-hydroxypyruvate was detected (Lactate dehydrogenase/NADH enzymatic assay). Proteins were precipitated with methanol $(170 \mathrm{~mL})$ and removed by centrifugation at $8000 \mathrm{rpm}$ for $15 \mathrm{~min}$. Dowex $50 \mathrm{WX} 8$ resin $\left(\mathrm{H}^{+}\right.$form, $\left.10 \mathrm{~mL}\right)$ was added, the mixture was stirred for $30 \mathrm{~min}$, and the resin was removed by filtration. Dowex $1 \mathrm{X} 8$ resin $\left(\mathrm{HCO}_{3}{ }^{-}\right.$form, $\left.10 \mathrm{~mL}\right)$ was added to the filtrate, and the mixture was stirred for $30 \mathrm{~min}$. After filtration of the resin, the solution was evaporated to dryness, and crude compound 2 was purified by flash column chromatography $\left(\mathrm{CH}_{2} \mathrm{Cl}_{2} / \mathrm{MeOH}, 8: 2\right)$ to afford $110 \mathrm{mg}$ of compound 2 ( $48 \%$ yield).

B Isomer: ${ }^{1} \mathrm{H}$ NMR (400 MHz, $\left.\mathrm{CD}_{3} \mathrm{OD}\right): \delta=2.57$ (dd, $J=9,10 \mathrm{~Hz}$, $1 \mathrm{H}, 5-\mathrm{H}), 3.03\left(\mathrm{dd}, J=8,10 \mathrm{~Hz}, 1 \mathrm{H}, 5^{\prime}-\mathrm{H}\right), 3.59(\mathrm{~d}, J=13 \mathrm{~Hz}$, $1 \mathrm{H}, 1-\mathrm{H}), 3.62$ (d, $\left.J=13 \mathrm{~Hz}, 1 \mathrm{H}, 1^{\prime}-\mathrm{H}\right), 3.73$ (d, $J=9 \mathrm{~Hz}, 1 \mathrm{H}, 3-$ $\mathrm{H}), 4.23-4.32$ (m, 1 H, 4-H) ppm. ${ }^{13} \mathrm{C} \mathrm{NMR}\left(100 \mathrm{MHz}, \mathrm{CD}_{3} \mathrm{OD}\right): \delta$ $=31.2(\mathrm{C}-5), 67.5(\mathrm{C}-1), 77.0(\mathrm{C}-4), 79.8(\mathrm{C}-3), 89.7$ (C-2) ppm. $\alpha$ Isomer: ${ }^{1} \mathrm{H}$ NMR $\left(400 \mathrm{MHz}, \mathrm{CD}_{3} \mathrm{OD}\right): \delta=2.94(\mathrm{dd}, J=5$, $11 \mathrm{~Hz}, 1 \mathrm{H}, 5-\mathrm{H}), 3.03\left(\mathrm{dd}, J=5,11 \mathrm{~Hz}, 1 \mathrm{H}, 5^{\prime}-\mathrm{H}\right), 3.73(\mathrm{~d}, J=$ $11 \mathrm{~Hz}, 1 \mathrm{H}, 1-\mathrm{H}), 3.81\left(\mathrm{~d}, J=11 \mathrm{~Hz}, 1 \mathrm{H}, 1^{\prime}-\mathrm{H}\right), 4.03(\mathrm{~d}, J=5 \mathrm{~Hz}$, $1 \mathrm{H}, 3-\mathrm{H}), 4.23-4.32(\mathrm{~m}, 1 \mathrm{H}, 4-\mathrm{H}) \mathrm{ppm} .{ }^{13} \mathrm{C}$ NMR $(100 \mathrm{MHz}$, $\left.\mathrm{CD}_{3} \mathrm{OD}\right): \delta=35.9$ (C-5), 66.8 (C-1), $79.0(\mathrm{C}-4), 83.9$ (C-3), 96.0 (C-2) ppm. HR-ESI-MS calculated for $\mathrm{C}_{5} \mathrm{H}_{10} \mathrm{O}_{4} \mathrm{NaS}[\mathrm{M}+\mathrm{Na}]^{+}$: 189.0198; found 189.0192 .

5-Chloro-D-xylulose (7): 2-Chloroacetaldehyde $(850 \mu \mathrm{L}, \mathrm{mmol})$ at $50 \%(\mathrm{w} / \mathrm{v})$ in water was added to an aqueous solution of DHAP $(60 \mathrm{~mL}, 5.7 \mathrm{mmol})$ at $\mathrm{pH} 6.8$. FruA $(200 \mathrm{U})$ was added. After $1 \mathrm{~h}$ an additional amount of 2-chloroacetaldehyde $(150 \mu \mathrm{L})$ was added to the reaction mixture and allowed to react for $18 \mathrm{~h}$ at room temperature. The $\mathrm{pH}$ of the water phase was adjusted to 4.7 with $\mathrm{HCl}$ $(1 \mathrm{~N})$, and acid phosphatase $(50 \mathrm{U})$ was added. The reaction mixture was shaken for a further $48 \mathrm{~h}$ at room temperature. After completion of the reaction, the $\mathrm{pH}$ was raised to 7.0 with $\mathrm{NaOH}(1 \mathrm{~N})$, and $\mathrm{MeOH}(180 \mathrm{~mL})$ was poured into the solution. The resulting precipitate was removed by filtration through celite. The filtrate was concentrated under vacuum. Column chromatography $\left(\mathrm{CH}_{2} \mathrm{Cl}_{2} /\right.$ $\mathrm{MeOH}, 9: 1)$ yielded 5-chloro-D-xylulose as a pale yellow oil (679 mg, 71\% from DHAP). ' $\mathrm{H}$ NMR $\left(400 \mathrm{MHz}, \mathrm{CD}_{3} \mathrm{OD}\right): \delta=$ $3.54(\mathrm{dd}, J=8,10 \mathrm{~Hz}, 1 \mathrm{H}, 5-\mathrm{H}), 3.70\left(\mathrm{dd}, J=8,10 \mathrm{~Hz}, 1 \mathrm{H}, 5^{\prime}\right.$ H), $4.10(\mathrm{td}, J=2,8 \mathrm{~Hz}, 1 \mathrm{H}, 4-\mathrm{H}), 4.39(\mathrm{~d}, J=2 \mathrm{~Hz}, 1 \mathrm{H}, 3-\mathrm{H})$, $4.47(\mathrm{~d}, J=19 \mathrm{~Hz}, 1 \mathrm{H}, 1-\mathrm{H}), 4.54\left(\mathrm{~d}, J=19 \mathrm{~Hz}, 1 \mathrm{H}, 1^{\prime}-\mathrm{H}\right) \mathrm{ppm}$. ${ }^{13} \mathrm{C}$ NMR (100 MHz, $\left.\mathrm{CD}_{3} \mathrm{OD}\right): \delta=45.1(\mathrm{C}-5), 67.9(\mathrm{C}-1), 73.6$ (C4), 76.7 (C-3), 212.5 (C-2) ppm. HR-ESI-MS: calculated for $\mathrm{C}_{5} \mathrm{H}_{9} \mathrm{ClNaO}_{4}[\mathrm{M}+\mathrm{Na}]^{+}$191.0087; found 191.0097.

5-Bromo-D-xylulose (8): 2-Bromoacetaldehyde (1.3 mL, $2 \mathrm{mmol})$ was added to an aqueous solution of DHAP $(60 \mathrm{~mL}, 5.7 \mathrm{mmol})$ at $\mathrm{pH}$ 6.8. FruA $(200 \mathrm{U})$ was added. After $1 \mathrm{~h}$ an additional amount of 2-bromoacetaldehyde $(150 \mu \mathrm{L})$ was added to the reaction mixture and allowed to react for $18 \mathrm{~h}$ at room temperature. The $\mathrm{pH}$ of the water phase was then adjusted to 4.7 with $\mathrm{HCl}(1 \mathrm{~N})$ and acid phosphatase $(50 \mathrm{U})$ was added. The reaction mixture was shaken for a further $48 \mathrm{~h}$ at room temperature. After completion of the reaction, the $\mathrm{pH}$ was raised to 7.0 with $\mathrm{NaOH}(1 \mathrm{~N})$, and $\mathrm{MeOH}$ $(180 \mathrm{~mL})$ was poured into the solution. The resulting precipitate was removed by filtration through celite. The filtrate was concentrated under vacuum. Column chromatography $\left(\mathrm{CH}_{2} \mathrm{Cl}_{2} / \mathrm{MeOH}\right.$, 9:1) yielded 5-bromo-D-xylulose as a pale yellow oil $(666 \mathrm{mg}, 55 \%$ from DHAP). ${ }^{1} \mathrm{H}$ NMR ( $\left.400 \mathrm{MHz}, \mathrm{CD}_{3} \mathrm{OD}\right): \delta=3.40$ (dd, $J=8$, $10 \mathrm{~Hz}, 1 \mathrm{H}, 5-\mathrm{H}), 3.58\left(\mathrm{dd}, J=8,10 \mathrm{~Hz}, 1 \mathrm{H}, 5^{\prime}-\mathrm{H}\right), 4.15(\mathrm{td}, J=$ 2, $8 \mathrm{~Hz}, 1 \mathrm{H}, 4-\mathrm{H}), 4.44$ (d, $J=2 \mathrm{~Hz}, 1 \mathrm{H}, 3-\mathrm{H}), 4.51(\mathrm{~d}, J=19 \mathrm{~Hz}$, $1 \mathrm{H}, 1-\mathrm{H}), 4.54\left(\mathrm{~d}, J=19 \mathrm{~Hz}, 1 \mathrm{H}, 1^{\prime}-\mathrm{H}\right) \mathrm{ppm} .{ }^{13} \mathrm{C}$ NMR $\left(100 \mathrm{MHz}, \mathrm{CD}_{3} \mathrm{OD}\right): \delta=33.4(\mathrm{C}-5), 67.9(\mathrm{C}-1), 73.7$ (C-4), 77.0 (C-3), 213.4 (C-2) ppm. HR-ESI-MS: calculated for $\mathrm{C}_{5} \mathrm{H}_{9} \mathrm{BrNaO}_{4}$ $[\mathrm{M}+\mathrm{Na}]^{+} 234.9582$; found 234.9577 .

5-Halo-D-xylulofuranose 7 and 8 (One-Pot Reaction from rac-Glycidol): Solid $\mathrm{Na}_{2} \mathrm{HPO}_{4}(3.71 \mathrm{~g}, 25 \mathrm{mmol})$ was added to a solution of rac-2,3-epoxypropanol $(1.9 \mathrm{~g}, 25 \mathrm{mmol}, 50 \mathrm{~mL})$ in distilled water. The mixture was heated at $100^{\circ} \mathrm{C}$ for $3 \mathrm{~h}$ and assayed for L-glycerol-3-phosphate content. The yield was $61 \%$ from $(S)$-2,3-epoxypropanol ( $30 \%$ from rac-2,3-epoxypropanol). To a solution containing L-glycerol-3-phosphate $(155 \mathrm{mM}, 10 \mathrm{~mL}$, based on enzymatic assay) at $\mathrm{pH} 6.8$ was added $\mathrm{GPO} /$ catalase mixture $(0.1 \mathrm{~mL}$, $45 \mathrm{U} / 1800 \mathrm{U})$, FruA $(0.07 \mathrm{~mL}, 20 \mathrm{U})$ and aldehyde (2-chloroacetaldehyde, $0.13 \mathrm{~mL}, 2 \mathrm{mmol}$ or 2-bromoacetaldehyde, $545 \mathrm{mg}$, $2 \mathrm{mmol}$. The reaction proceeded with stirring at room temperature overnight. The $\mathrm{pH}$ was adjusted to 4.7 with $\mathrm{HCl}(1 \mathrm{~N})$ and acidic phosphatase $(50 \mathrm{U})$ was added. The reaction mixture was shaken for another $24 \mathrm{~h}$ at room temperature. The $\mathrm{pH}$ was raised to 7.0 with $\mathrm{NaOH}(1 \mathrm{~N})$, and $\mathrm{MeOH}(30 \mathrm{~mL})$ was poured into the solu- 
tion. The resulting precipitate was removed by filtration through celite. The filtrate was concentrated under vacuum, and the brown residue underwent silica gel chromatography in the same conditions as already described. 5-bromo-D-xylulose was obtained as a light yellow oil in $12 \%$ yield. 5-chloro-D-xylulose was recovered as a light yellow oil in $47 \%$ yield.

\section{5-Thio-D-xylulofuranose (2) from 5-Halo-D-xylulose 7 or 8}

Method A. $\mathrm{Na}_{3} \mathrm{SPO}_{3}$ as the Nucleophile: To a solution of 5-haloD-xylulose 7 or $8(0.62 \mathrm{mmol})$ in distilled water $(2 \mathrm{~mL})$ was added a solution of $\mathrm{Na}_{3} \mathrm{SPO}_{3}(0.65 \mathrm{mmol})$ in distilled water $(2 \mathrm{~mL})$. The $\mathrm{pH}$ of the resulting mixture was kept at 10 by adding $\mathrm{NaOH}(2 \mathrm{~N})$. After $3 \mathrm{~h}$ at room temperature and with stirring, the $\mathrm{pH}$ was lowered to 4.0 with $\mathrm{HCl}(1 \mathrm{~N})$, and the reaction was allowed to proceed overnight. The $\mathrm{pH}$ was adjusted to 8.2 before the addition of $\mathrm{BaCl}_{2}$ $(1 \mathrm{~mL}, 0.65 \mathrm{mmol}$, a solution in water). The white precipitate was isolated by centrifugation at $3500 \mathrm{rpm}$ for $15 \mathrm{~min}$ and discarded. The supernatant was concentrated under vacuum and subjected to flash chromatography on silica $\left(\mathrm{CH}_{2} \mathrm{Cl}_{2} / \mathrm{MeOH}, 9: 1\right)$. 5-thio-D-xylulofuranose (2) was recovered as its $\alpha$ and $\beta$ isomers $(\alpha / \beta, 87: 13)$ as a pale yellow oil in $55 \%$ yield, irrespective of whether 5-halo-Dxylulose 7 or $\mathbf{8}$ was used as the starting material. Analytical data were identical to those previously given.

Method B. NaSH as the Nucleophile: The NaSH. $x \mathrm{H}_{2} \mathrm{O}$ reagent was added $(0.532 \mathrm{~g})$ to a solution of 5-halo-D-xylulose $(4.75 \mathrm{mmol})$ in distilled water $(70 \mathrm{~mL})$. The yellow solution was shaken at room temperature for $3 \mathrm{~h}$ and kept at $4{ }^{\circ} \mathrm{C}$ overnight. The solvents were eliminated under reduced pressure, and the crude product was purified by flash column chromatography on silica gel. The desired compound 2 was eluted with $\mathrm{CH}_{2} \mathrm{Cl}_{2} / \mathrm{MeOH}(85: 15)$. It was isolated as its $\alpha$ and $\beta$ isomers $(\alpha / \beta, 87: 13)$ in $61 \%(2.9 \mathrm{mmol})$ and $57 \%$ ( $2.7 \mathrm{mmol})$ yield starting from 5-chloro- and 5-bromo-D-xylulose, respectively. Analytical data were identical to those previously given.

5-Thio-D-xylopyranose (1): Into a capped vial was introduced an aqueous solution of 5-thio-D-xylulofuranose $2(100 \mathrm{~mm}$ or $200 \mathrm{mM}$, $4 \mathrm{~mL})$, followed by phosphoric acid $(5 \mu \mathrm{L}, 85 \%)$. The $\mathrm{pH}$ of the solution was adjusted to 7.5 with $\mathrm{NaOH}(90 \mu \mathrm{L}, 2 \mathrm{~N})$. Stock solutions of $\mathrm{Co}^{2+}(100 \mathrm{mM}, 38 \mu \mathrm{L}), \mathrm{Mg}^{2+}(100 \mathrm{mM}, 38 \mu \mathrm{L})$ and $\mathrm{Mn}^{2+}$ $(50 \mathrm{mM}, 19 \mu \mathrm{L})$ were then added. Two different processes were investigated. In Process A, the reaction was initiated by pouring GlcI $(106 \mathrm{mg}, 45 \mathrm{U})$ into the mixture and letting it react at $48^{\circ} \mathrm{C}$ (optimum temperature for $\mathrm{GlcI}$ ) for $8 \mathrm{~d}$. Aliquots were analysed at intervals by HPLC to monitor the course of the reaction. For Process $\mathrm{B}$, all conditions were the same, except for an additional amount of GlcI $(106 \mathrm{mg}, 45 \mathrm{U})$ added to the medium every $24 \mathrm{~h}$.

Starting with 5-thio-D-xylulofuranose (2) at $100 \mathrm{~mm}$ and using Process $\mathrm{B}$, the ketose/aldose ratio rose to $40: 60$ in favour of 5-thio-Dxylopyranose after $8 \mathrm{~d}$ at $48^{\circ} \mathrm{C}$. After removal of the protein by ultracentrifugation, the reaction mixture was subjected to semi-preparative HPLC. Purification of 1 was performed with a $\mu$ Bondapak $\mathrm{NH}_{2}$ column $(4.0 \mathrm{~mm} \times 150 \mathrm{~mm})$ under the following conditions: $\mathrm{CH}_{3} \mathrm{CN} / \mathrm{H}_{2} \mathrm{O}, 5 \mathrm{mLmin}^{-1}, 25^{\circ} \mathrm{C}$, injection volume $10 \mu \mathrm{L}, 4 \mathrm{mg}$.

Compound 1 was recovered in $60 \%$ yield $(40 \mathrm{mg})$. The structure of compound 1 was confirmed by ${ }^{1} \mathrm{H}$ and ${ }^{13} \mathrm{C}$ NMR spectroscopy. The data exactly fit those of the literature. ${ }^{[1]}$

\section{Acknowledgments}

We thank Professor G. Schneider (Karolinska Institut, Stockholm, Sweden) for the gift of the yeast strain $\mathrm{H} 402$ transformed with pTKL1. We thank also Fournier Pharma for financial support.
[1] a) H. Paulsen, K. Todt, Adv. Carbohydr. Chem. 1968, 23, 115 232; b) I. Robina, P. Vogel, Z. J. Witczak, Curr. Org. Chem. 2001, 5, 1177-1214; c) I. Robina, P. Vogel, Curr. Org. Chem. 2002, 6, 471-491.

[2] D. Horton, J. D. Wander, The Carbohydrate, Chemistry and Biochemistry; $2^{\text {nd }}$ ed. (Eds.: W. Pigman, D. Horton), vol. IB, Academic Press, New York, 1980, 799-842.

[3] S. Samreth, V. Barberousse, F. Bellamy, D. Horton, P. Masson, J. Millet, P. Renaut, C. Sepulchre, J. Thevenaiux, Actual. Chim. Thér. 1994, 21, 23-33

[4] F. Bellamy, D. Horton, J. Millet, F. Picard, S. Samreth, J. B. Chazan, J. Med. Chem. 1993, 36, 898-903.

[5] H. Paulsen, Angew. Chem. Int. Ed. Engl. 1982, 21, 155-173.

[6] R. R. Schmidt, Angew. Chem. Int. Ed. Engl. 1986, 25, 212-235.

[7] H. Kunz, Angew. Chem. Int. Ed. Engl. 1987, 26, 294-308.

[8] R. L. Whistler, T. Van Es, J. Org. Chem. 1963, 28, 2303-2304.

[9] D. L. Ingles, R. L. Whistler, J. Org. Chem. 1962, 27, 3896-3898.

[10] a) J. C. Schwarz, K. C. Yule, Proc. Chem. Soc. London 1961, 417; b) T. J. Adley, L. N. Owen, Proc. Chem. Soc. London 1961, 418.

[11] J. Lalot, I. Stasik, G. Demailly, D. Beaupère, Carbohydr. Res. 2003, 338, 2241-2245.

[12] J. R. Durrwachter, D. G. Drueckhammer, K. Nozaki, H. M. Sweers, C.-H. Wong, J. Am. Chem. Soc. 1986, 108, 7812-7818.

[13] W.-C. Chou, L. Chen, J.-M. Fang, C.-H. Wong, J. Am. Chem. Soc. 1994, 116, 6191-6194.

[14] W.-D. Fessner, C. Gosse, G. Jaeschke, O. Eyrisch, Eur. J. Org. Chem. 2000, 125-132.

[15] a) T. Ziegler, A. Straub, F. Effenberger, Angew. Chem. Int. Ed. Engl. 1988, 27, 716-721; b) Y. Kobori, D. C. Myles, G. M. Whitesides, J. Org. Chem. 1992, 57, 5899-5907; c) K. G. Morris, M. E. B. Smith, N. J. Turner, Tetrahedron: Asymmetry 1996, 7 , 2185-2188; d) F. T. Zimmermann, A. Schneider, Y. Schörken, G. A. Sprenger, W. D. Fessner, Tetrahedron: Asymmetry 1999 , 10, 1643-1646; e) L. Hecquet, J. Bolte, C. Demunyck, Tetrahedron 1996, 52, 8223-8232; f) C. Guérard, V. Alphand, A. Archelas, C. Demuynck, L. Hecquet, R. Furstoss, J. Bolte, Eur. J. Org. Chem. 1999, 1, 3399-3402; g) D. Crestia, C. Guérard, H. Veschambre, L. Hecquet, C. Demuynck, J. Bolte, Tetrahedron: Asymmetry 2001, 12, 869-876.

[16] a) M. D. Bednarski, E. S. Simon, N. Bischofberger, W. D Fessner, M. J. Kim, W. Lees, T. Saito, H. Waldmann, G. M. Whitesides, J. Am. Chem. Soc. 1989, 111, 627-635; b) C. Andre, C. Guerard, L. Hecquet, C. Demuynck, J. Bolte, J. Mol. Catal. B: Enzym. 1998, 5, 459-466; c) L. Espelt, T. Parella, J. Bujons, C. Solans, J. Joglar, A. Delgado, P. Clapes, Chem. Eur. J. 2003, 9, 4887-4899; d) L. El Blidi, D. Crestia, E. Gallienne, C. Demuynck, J. Bolte, M. Lemaire, Tetrahedron: Asymmetry 2004. 15, 2951-2954.

[17] Z. Liu, L. M. Sayre, Chem. Res. Toxicol. 2003, 16, 232-241.

[18] F. Effenberger, A. Straub, V. Null, Liebigs Ann. Chem. 1992, $12,1297-1301$.

[19] F. Effenberger, V. Null, T. Ziegler, Tetrahedron Lett. 1992, 33 , $5157-5160$.

[20] As determined enzymatically through DHAP monitoring by NADH-consuming glycerol-3-phosphate dehydrogenase in the presence of triose phosphate isomerase.

[21] W. B. Knight, D. S. Sem, K. Smith, H. M. Miziorko, A. Rendina, W. W. Cleland, Biochemistry 1991, 30, 4977-4979.

[22] a) O. Meyer, M. Rohmer, C. Grosdemange-Billiard, Tetrahedron Lett. 2004, 45, 7921-7923; b) N. Ouwerkerk, M. Steenweg, M. De Ruijter, J. Brouwer, J. H. Van Boom, J. Lugtenburg, J. Raap, J. Org. Chem. 2002, 67, 1480-1489; c) E. L. Ferroni, V. DiTella, N. Ghanayem, R. Jeske, C. Jodlowski, M. O'Connell, J. Styrski, R. Svodoba, A. Venkataraman, B. M. Winkler, J. Org. Chem. 1999, 64, 4943-4945; d) T. Gefflaut, M. Valentin, M.-L. Lemaire, J. Bolte, J. Org. Chem. 1997, 62, 5920-5922; e) M.-L. Valentin, J. Bolte, Bull. Soc. Chim. Fr. 1995, 132, 1167- 
1171; f) S.-H. Jung, J.-H. Jeong, P. Miller, C.-H. Wong, J. Org. Chem. 1994, 59, 7182-7184.

[23] F. Charmantray, P. Dellis, S. Samreth, L. Hecquet, Tetrahedron Lett. 2006, 47, 3261-3263.

[24] S. H. Bhosale, M. B. Rao, V. V. Deshpande, Microbiol. Rev. 1006 6n 280300
[25] L. Wikner, U. Meshalkina, M. Nikkola, Y. Lindqvist, G Schneider, J. Biol. Chem. 1994, 269, 32144-32150.

[26] H. U. Bergmeyer, Methods in Enzymatic Analysis, 34th ed., Verlag Chemie, 1984, 11, 146-147.

Received: July 20, 2006 Duhlishad Onlina. Octoher 10 3006 